\title{
Distance Education during the COVID-19 Pandemic: The Impact of Online Gaming Addiction on University Students' Performance
}

\author{
Mahmoud Abou Naaj, Mirna Nachouki \\ Department of Information Technology \\ Ajman University, Ajman \\ UAE
}

\begin{abstract}
The COVID-19 pandemic has forced most universities worldwide to convert to distance education to ensure the educational process remains uninterrupted. The COVID-19 pandemic-related confinement orders have led students to be more engaged with online games. However, for a minority of students, excessive playing can become problematic and addictive. Few studies investigated the long-term effect of COVID-19 on game addiction among university students. The present study investigates the changes in online game addiction rates between May 2021 and May 2020 and aims at determining the impact of playing online games on students' academic performance. It also examines the demographic factors associated with video game addiction. A sample $(n=418)$ of students from one private university in UAE was randomly selected, and data were analyzed. The study has determined a reduction in online game addiction levels in the second year of pandemic compared with the first year. Gender and academic level were considered the most predominant features expressively related to online games addiction. It has also been found that digital game addiction is positively associated with academic performance.
\end{abstract}

Keywords-Distance education; COVID-19 pandemic; game addiction; students' performance

\section{INTRODUCTION}

In modern society, most of the information is collected from the internet, thus using electronic devices has become an essential means in all living areas. In particular, United Arab Emirates (UAE) emphasized the importance of building highspeed information infrastructures and informatization education at the national level. The statistic demonstrates that the UAE has the highest internet diffusion rate as of January 2021. It was found that 99 percent of the UAE population has access to the internet [1]. Playing games is one of the most common leisure activities for young people. It has been continuously increasing with the development of the internet and smart devices.

The emergence of the deadly COVID-19 pandemic at the end of 2019, which gradually swept all over the globe, brought instant and dramatic changes. People, who were required to stay at home, increased their consumption of all kinds of digital entertainment, especially online games [2,3]. For instance, $75 \%$ increase had been recorded in online gaming activity since COVID-19 pandemic stay-at-home instructions in USA
[4], with more than 20 million concurrent active users [5]. In addition, online gaming has been perceived as amplified due to public health efforts to encourage social distancing [6].

To control and decrease virus transmission, the governments in many countries worldwide, including the United Arab Emirates, implemented mandatory closure of educational institutions and all their face-to-face teaching and learning activities. This shift from traditional face-to-face learning to distance learning instruction greatly impacted everyone involved, particularly students. They registered for face-to-face education but suddenly switched from the conventional learning style they preferred and were accustomed to.

The lockdown caused by the COVID-19 pandemic may have further increased their use of online video games and, therefore, the risk of video gaming addiction. While moderate use of online gaming could lead to wide-ranging benefits [7], extreme usage of this activity experimented with various social problems and addictions [8]. The pandemic has contributed to increasing video game addiction in general and among students [9].

However, we do not currently have a thorough knowledge of the effect of the COVID-19 pandemic on students. Therefore, the current study will analyze video gaming addiction among university students during the lockdown, starting in March 2020.

Furthermore, few studies have been conducted to examine the relationship between playing video games and academic performance, especially in the United Arab Emirates. Most video game studies focus on the behavioral effects of video games. This issue makes it essential to determine whether the increased time spent playing online games during pandemics influenced students' academic performance. The study also identifies the main demographic factors (age, gender, academic level) related to online video game addiction.

Educational institutions, instructors can benefit from the findings of this research to shift their pedagogical approach from lecture-centered to student-centered and integrate the use of games as innovative learning technologies into their curricula. 


\section{LITERATURE REVIEW}

The Covid-19 pandemic has affected teaching and learning at almost all higher education institutions worldwide. Most universities have faced sudden pressure to change from faceto-face courses to digitally enhanced teaching for distance learning. Two-thirds had reported replacing face-to-face classroom teaching with distance teaching and learning [10]. The pandemic also increased the risk of video game addiction among students [9].

Most of the students play video games, and it is known that video games are a common form of entertainment [11]. In addition, games are often seen as an important part of new technologies, and they have become an essential part of many students' lives [12]. However, students' online video game usage has generated significant concern due to its possible adverse effects on their health, socialization, and academic performance. Regarding this last aspect, some studies point out that online video games negatively affect academic performance, while others emphasize their positive effects.

Games can enhance logical thinking, analytical skills, social skills, visual abilities, collaboration, movement, and computing [13]. Psychomotor processes are influenced by computer and video games, and tension levels are reduced. In addition, playing games improve critical reasoning, analytical capabilities, movement, cognitive skills, perceptual ability, teamwork, and programming [14]. A study by [15] showed a positive relationship between the number of hours students play video games and their GPA, which means that students who take time playing video games can have better academic performance. Also, the author in [13] states that students' awareness and consciousness can be improved by playing video games. Online video games play an important role in increasing students' intelligence quotients (IQ). When students play games in the classroom, they form teams and devise their tactics for winning. They pay attention to and analyze the key points, aiming to minimize future challenges by looking more seriously [16]. The study of [14] found that $72 \%$ of participants believed that homework tasks involving computer or video games outside of the classroom could be a benefit to student education. In addition, about $77 \%$ accepted that video games should be used to incorporate and teach science, technology, and mathematics principles.

As stated by [13], video games can enhance logical thinking, analytical skills, social skills, visual abilities, collaboration, movement, and computing. Therefore, there can be a positive impact on student's GPA/academic achievements caused by video games. However, some studies, such as [12], states that video games cause negatively on students' academic performance due to addiction and distraction. Therefore, there is mixed information about the relation between video games and student's academic performance.

Students who did play video games had meaningfully lower GPAs than those who stated that they did not play video games [17]. This conclusion is similar to the study [18], which noticed a decrease in GPA and SAT scores for video game students. Therefore, it is more reliable to use GPA as it represents a continuous assessment of academic performance. This conclusion also matches the findings of [19], who experimented with decreases in academic performance for students who played video games.

Although there is no specific definition for the term video game addiction, it was found that students addicted to playing games had lower academic performance. Moreover, time spent playing online games was found as a negative indicator of academic performance for undergraduate students [20].

A study performed by [21] had used open-ended questions to encourage students to report their moods while playing video games. As a result, various negative repercussions indirectly related to academic performance associated with addiction to video gaming were reported, such as skipping classes, missing homework deadlines, etc. Researchers also found that these repercussions directly involved gender, an important demographic factor of video game addiction, as male students tend to play more often and lean towards losing time while playing. This statement was also confirmed by [18], who found that the academic performance of male students was more affected as they spent more time playing video games.

An experiment proved that academic performance improved after the students completely decreased their usage time of all technology, including video games, with a maximum of 30 minutes allowed per day. On the other hand, [22] found that playing video games for more than five hours per session has a negative impact on academic performance. They also found that these excessive hours spent on gaming promoted violence among students and prevented them from having normal social interaction and extra-curricular activities.

\section{PURPOSE OF THE STUDY}

The purpose of the study is:

- Check whether a change in students' online video game addiction is noticeable between May 2020 and May 2021,

- Observe the effects of some demographic factors (age, gender, academic level) on online video game addiction,

- Explore the impact of online video gaming on student's academic performance.

\section{Methodology}

\section{A. Participants}

A total of 418 participants from one private university in the UAE were randomly selected to participate in this crosssectional study. A survey questionnaire was applied to collect data from students in May 2020 and May 2021. In all, $101(24 \%)$ students had completed the survey form in May 2021 and $317(76 \%)$ students completed the survey in May 2020. Fig. 1 represents the demographic data of the students who participated in the survey. Of those who completed the survey form, $187(45 \%)$ were males, whereas $231(55 \%)$ were females. A total of $138(33 \%)$ of the participant were aged less than or equal 20, $263(63 \%)$ aged between 21 and 25, $14(3 \%)$ aged between 26 and 29, and $3(1 \%)$ aged 30 or above. A total $290(69 \%)$ of the participant has completed less than 90 credit hours, and $128(31 \%)$ has completed 90 credit or above. $5(1 \%)$ 
participants have CGPA less than 2, $80(19 \%)$ have a CGPA between 2 and 2.49, $105(25 \%)$ have a CGPA between 2.5 and 2.99, $129(31 \%)$, or have a CGPA between 3 and 3.59 while 98 $(24 \%)$ has a CGPA of 3.6 or above.
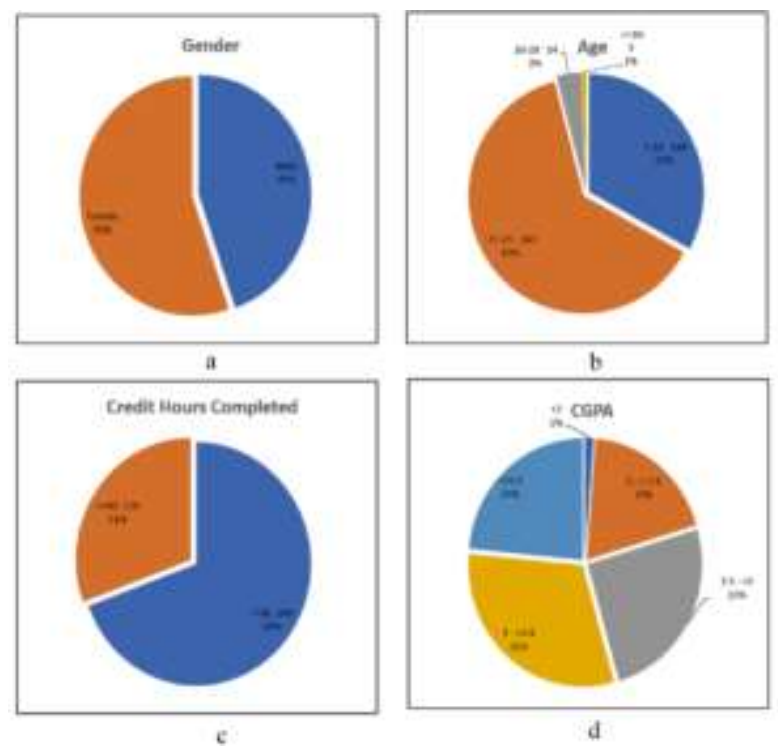

Fig. 1. Demographic Data of the Students who participated in the Survey

\section{B. Instrument}

The research instrument consisted of a self-report questionnaire with a three-part structure designed to collect student's responses. The first section collected demographical/personal data based on five items related to participants' profiles, including age, gender, CGPA, major, and the number of credit hours completed. The second part consists of four questions. The first question was, "On average, how many hours do you spend playing video games daily?". The second question was, "Does gaming overall give you any real fulfillment in life?". The third question was, "If it is needed, could you quit playing video games easily?". While the fourth question was, "Did the average daily time you spend playing video games increase during the COVID-19 Pandemic?". Part 3 consisted of 20 items. The statement preceded them: "How often in the last six months...? All items were scored on the 5point Likert scale, ranging from 1(never), 2(rarely), 3 (sometimes), 4 (often), and 5 (very often). These items were mainly based on a review of the literature.

\section{Reliability}

The researchers performed a reliability analysis using Cronbach's alpha to determine the internal questionnaire consistency once the data collection phase was completed. The satisfaction scale's alpha reliability coefficient was 0.956 , which indicated that the instrument was highly reliable.

\section{Research Hypotheses}

The research hypotheses are listed below:

H1: There is no significant change in students' online game addiction between May 2020 and May 2021.

$\mathrm{H} 2$ : There is no significant relationship between gender and online game addiction.
H3: There is no significant relationship between academic level and online game addiction.

H4: There is no significant relationship between age and online game addiction.

H5: Online game addiction has no significant impact on academic performance.

\section{E. Data Analysis}

Data analysis was conducted using the IBM SPSS Statistics version 27. An independent t-test was used to examine the relationships between video game addition, gender, academic level. In addition, between-participants one-way ANOVA was used to assess the effects of variables (age) on video game addiction and time spent gaming. Also, the one-way ANOVAs test was used to determine if video game addiction and time spent gaming affect academic performance. All statistical analysis was two-tailed with a .05 level of significance. Finally, linear regression was used to find out whether there is a correlation between CGPA and Addiction Hours.

\section{RESUlT AND DISCUSSION}

Based on Fig. 2a, the question "On average, how many hours do you spend playing video games daily?". 15\% of the participants do not play video games, followed by $50 \%$ of the participants play on average 2 hours daily. $27 \%$ of the participants play on average 5 hours daily, while $6 \%$ play on average 8 hours daily, and finally $2 \%$ of the participants play on average 10 hours every day.

Based on Fig. 2b, the question "Does gaming overall give you any real fulfillment in life?". $48 \%$ of the participants said yes, $14 \%$ were neutral, while 38 said no. Then, based on Fig. $2 \mathrm{c}$, the question "If it was needed, could you quit playing video games easily?". $58 \%$ of the participants said yes, $8 \%$ were neutral, while $34 \%$ said no. Finally, based on Fig. 2d., the question "Did the average daily time you spend playing video games increase during COVID-19 Pandemic?". 146 (35\%) of the participants said yes, $66(16 \%)$ were neutral, while 206 (49\%) said no.
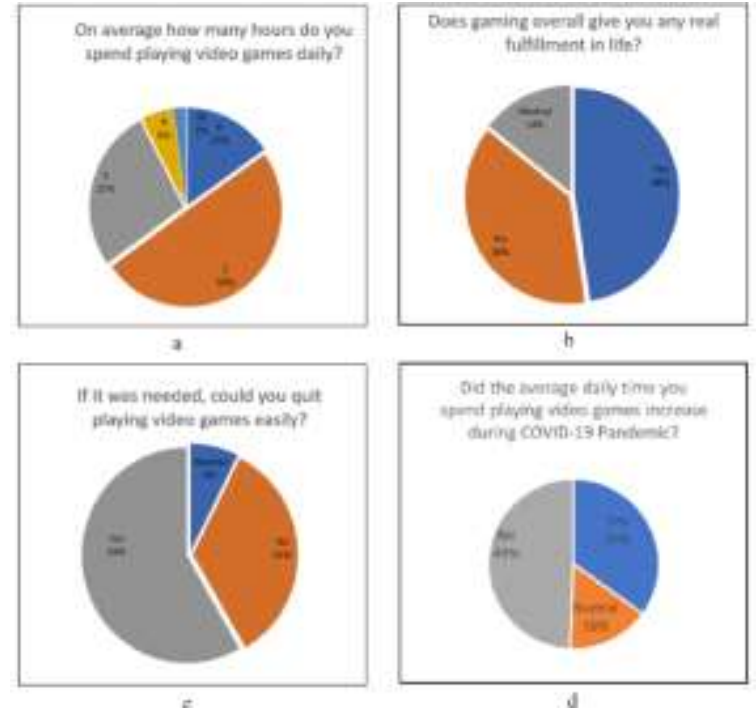

Fig. 2. Students responses with regards to their Gaming Behavior. 


\section{A. Comparison between May 2020 and May 2021 Survey} Analysis

H1: There is no significant change in students' online game addiction between May 2020 and May 2021.

An independent t-test was used to test hypothesis H1. The results of the testing are reported in Table 2. The test aimed to determine if students surveyed in May 2020 have the same online games addiction level as those surveyed in May 2021. The result shows that there is a statistically important difference students surveyed in May 2020 online games addiction level $($ Mean $=2.45$, Standard Deviation $=1.215)$ and on May 2021 online games addiction level (Mean= 2.044, Standard Deviation $=1.188 ; \mathrm{t}(416)=3.286, \mathrm{p}=0.010)$. Consequently, hypothesis $\mathrm{H} 1$ was rejected.

In conclusion, this result reveals an important difference between May 2020 students' online games addiction and May 2021 students' online games addiction. Specifically, in May 2021, students are less addicted to online games.

The average addiction hours for students surveyed in May 2020 was 3 hours, while 2.84 hours for those surveyed in May 2021.

\section{B. Gender}

$\mathrm{H} 2$ : There is no significant relationship between gender and online games addiction.

An independent t-test was used to test hypothesis $\mathrm{H} 2$. The results of the testing are reported in Table 2 . The test aimed to determine if female and male students have the same online games addiction level. The result shows that there is a statistically important difference in male students' video game addiction (Mean $=2.58$, Standard Deviation $=1.159)$ and female students' video game addiction (Mean $=2.198$, Standard Deviation $=1.198 ; \mathrm{t}(317)=3.436, \mathrm{p}=0.012$ ). Consequently, hypothesis $\mathrm{H} 2$ was rejected.

In conclusion, this result reveals an important difference in students' online game addiction between male and female students. Specifically, female students are less addicted to online games than their male counterparts.

The researchers also conducted another independent t-test shown in Table 1. The test aimed to determine if female and male students spend the same time playing video games. The result shows that there is a statistically important difference in male students' video game addiction (Mean $=3.55$, Standard Deviation $=2.253$ ) and female students' video game addiction $($ Mean $=2.48$, Standard Deviation $=2.234 ; \mathrm{t}(416)=4.139, \mathrm{p}=$ $0.000)$.

In conclusion, male students spent more time playing online games than their female counterparts.

\section{Academic Level}

H3: There is no significant relationship between academic level and online games addiction.

An independent t-test was used to test hypothesis H3. The results of the testing are reported in Table 2. The test aimed to determine if senior students (completed 90 credit hours or more) and junior students (completed less than 90 credits hours) have the same video game addiction level. The result shows that there is a statistically important difference between senior online games add (Mean $=2.08$, Standard Deviation $=$ $1.130)$ and junior students' video game addiction (Mean $=2.50$, Standard Deviation $=18130 ; \mathrm{t}(416)=4.435, \mathrm{p}=.001)$. Consequently, hypothesis $\mathrm{H} 3$ was rejected.

In conclusion, this result means a significant difference in students' video game addiction levels between senior and junior students.

TABLE I. INDEPENDENT SAMPLE T-TEST ANALYSIS RELATED TO STUDENTS' TIME SPENT ON VIDEO GAMES WITH REGARDS TO THEIR GENDER

\begin{tabular}{|c|c|c|c|}
\hline \multirow{2}{*}{\multicolumn{2}{|c|}{$\begin{array}{l}\text { Category } \\
\text { St. Type }\end{array}$}} & \multicolumn{2}{|l|}{ Gender } \\
\hline & & Male & Female \\
\hline \multicolumn{2}{|l|}{$N^{0}$ of Participants } & 187 & 231 \\
\hline \multicolumn{2}{|l|}{ Mean } & 3.55 & 2.48 \\
\hline \multicolumn{2}{|l|}{ Standard Deviation } & 2.253 & 2.34 \\
\hline \multicolumn{2}{|l|}{$\mathbf{t}$} & \multicolumn{2}{|l|}{4.852} \\
\hline \multicolumn{2}{|l|}{ df } & \multicolumn{2}{|l|}{416} \\
\hline \multicolumn{2}{|l|}{$\mathbf{p}$} & \multicolumn{2}{|l|}{0.000} \\
\hline \multirow{2}{*}{$\begin{array}{l}95 \% \text { Confidence Interval of the } \\
\text { Difference }\end{array}$} & Lower & \multicolumn{2}{|l|}{0.636670} \\
\hline & Upper & \multicolumn{2}{|l|}{1.503895} \\
\hline
\end{tabular}

TABLE II. InDEPENDENT SAMPLE TEST ANALYSIS RELATED TO StUdENTS' ONLINE GAME AdDiction

\begin{tabular}{|c|c|c|c|c|c|c|c|c|c|}
\hline \multirow[b]{2}{*}{ Category } & \multirow[b]{2}{*}{ Students' type } & \multirow[b]{2}{*}{ Number of Participants } & \multirow[b]{2}{*}{ Mean } & \multirow[b]{2}{*}{ SD } & \multirow[b]{2}{*}{$\mathbf{t}$} & \multirow[b]{2}{*}{ df } & \multirow[b]{2}{*}{$\mathbf{p}$} & \multicolumn{2}{|c|}{$\begin{array}{l}\text { 95\% Confidence Interval of } \\
\text { the Difference }\end{array}$} \\
\hline & & & & & & & & Lower & Upper \\
\hline \multirow{2}{*}{ Gender } & Male & 187 & 2.58 & 1.159 & \multirow{2}{*}{3.436} & \multirow{2}{*}{416} & \multirow{2}{*}{0.0012} & \multirow{2}{*}{0.162} & \multirow{2}{*}{0.602} \\
\hline & Female & 231 & 2.198 & 1.11916 & & & & & \\
\hline \multirow{2}{*}{ Students } & May 2020 & 317 & 2.45 & 1.215 & \multirow{2}{*}{3.286} & \multirow{2}{*}{416} & \multirow{2}{*}{0.010} & \multirow{2}{*}{0.172} & \multirow{2}{*}{0.684} \\
\hline & May 2021 & 101 & 2.044 & 1.1188 & & & & & \\
\hline \multirow{2}{*}{ Level } & Junior & 291 & 2.50 & 1.143 & \multirow{2}{*}{3.435} & \multirow{2}{*}{416} & \multirow{2}{*}{0.001} & \multirow{2}{*}{0.179} & \multirow{2}{*}{0.655} \\
\hline & Senior & 127 & 2.08 & 1.130 & & & & & \\
\hline
\end{tabular}




\section{Age}

Students were divided into four groups. Groups 1 for students who are less than or equal to 20 years old. Group 2 for students between 21 and 25 years old, group 3 for students between 26 and 29 years old, and group 4 for students who are 30 years or older. One-way ANOVA test analysis determined whether video game addiction and time spent playing video games differ significantly based on age. Table 3 indicates that university students' level of video game addiction does not differ according to age $(\mathrm{p}=.196)$. In addition, table 4 indicates that the time spent playing video games does not differ according to age $(\mathrm{p}=.871)$. Consequently, hypothesis $\mathrm{H} 4$ was accepted.

\section{E. Academic Performance}

In order to check whether video game addiction affects academic performance, the participants were divided into five groups. Groups 1 includes students with CGPA less than 2, group 2 for students with CGPA between 2 and 2.49, group 3 for students with CGPA between 2.5 and 2.99, group 4 for students with CGPA between 3.0 and 3.59 , and finally group 5 for student CGPA between 3.6 and 4.0. One-way ANOVA test analysis was used to determine whether video game addiction and time spent playing video games are associated with academic performance. Table 5 indicates that university students' level of video game addiction is significantly different between CGPA groups $(\mathrm{p}=.000)$. Fig. 3 shows that the mean for game addiction decreases as CGPA increase. Table 6 indicates that the time spent playing video games is significantly different between CGPA groups $(p=.000)$. Fig. 4 shows that the mean time spent playing video games decreases as CGPA increase.

Hypothesis H5 was rejected in both tests. This confirms that video game addiction has a significant impact on academic performance. Furthermore, students addicted to video games have worse performance than those who are less addicted.

TABLE III. ONE-WAY ANOVA RESUlts FOR THE LEVEL OF VIDEO GAME ADDICTION OF UNIVERSITY STUDENTS AGE

\begin{tabular}{|l|l|l|l|l|l|}
\hline \multicolumn{7}{|l|}{ ANOVA } \\
\hline AddicHRs & $\begin{array}{l}\text { Sum of } \\
\text { Squares }\end{array}$ & df & $\begin{array}{l}\text { Mean } \\
\text { Square }\end{array}$ & F & Sig. \\
\hline Between Groups & 26.724 & 3 & 8.908 & 1.572 & .196 \\
\hline Within Groups & 1813.227 & 320 & 5.666 & & \\
\hline Total & 1839.951 & 323 & & & \\
\hline
\end{tabular}

TABLE IV. ONE-WAY ANOVA RESULTS For TIME SPENT IN VIDEO GAME ADDICTION OF UNIVERSITY STUDENTS

\begin{tabular}{|l|l|l|l|l|l|}
\hline \multicolumn{7}{|l|}{ ANOVA } \\
\hline MeanofResp & $\begin{array}{l}\text { Sum of } \\
\text { Squares }\end{array}$ & df & $\begin{array}{l}\text { Mean } \\
\text { Square }\end{array}$ & F & Sig. \\
\hline Between Groups & .534 & 3 & .178 & .237 & .871 \\
\hline Within Groups & 240.763 & 320 & .752 & & \\
\hline Total & 241.297 & 323 & & & \\
\hline
\end{tabular}

TABLE V. ONE-WAY ANOVA RESULTS FOR THE LEVEL OF VIDEO GAME ADDICTION OF UNIVERSITY STUDENTS CGPA

\begin{tabular}{|l|l|l|l|l|l|}
\hline \multicolumn{7}{|l|}{ ANOVA } \\
\hline MeanofResp & $\begin{array}{l}\text { Sum of } \\
\text { Squares }\end{array}$ & df & $\begin{array}{l}\text { Mean } \\
\text { Square }\end{array}$ & F & Sig. \\
\hline Between Groups & 56.936 & 4 & 14.234 & 23.954 & .000 \\
\hline Within Groups & 244.821 & 412 & .594 & & \\
\hline Total & 301.757 & 416 & & & \\
\hline
\end{tabular}

TABLE VI. ONE-WAY ANOVA RESULTS FOR TIME SPENT IN VIDEO GAME ADDICTION OF UNIVERSITY STUDENTS WITH REGARDS TO CGPA

\begin{tabular}{|l|l|l|l|l|l|}
\hline \multicolumn{7}{|l|}{ ANOVA } \\
\hline AddicHRs & $\begin{array}{l}\text { Sum of } \\
\text { Squares }\end{array}$ & df & $\begin{array}{l}\text { Mean } \\
\text { Square }\end{array}$ & F & Sig. \\
\hline Between Groups & 98.762 & 4 & 24.691 & 4.876 & .001 \\
\hline Within Groups & 2086.077 & 412 & 5.063 & & \\
\hline Total & 2184.839 & 416 & & & \\
\hline
\end{tabular}

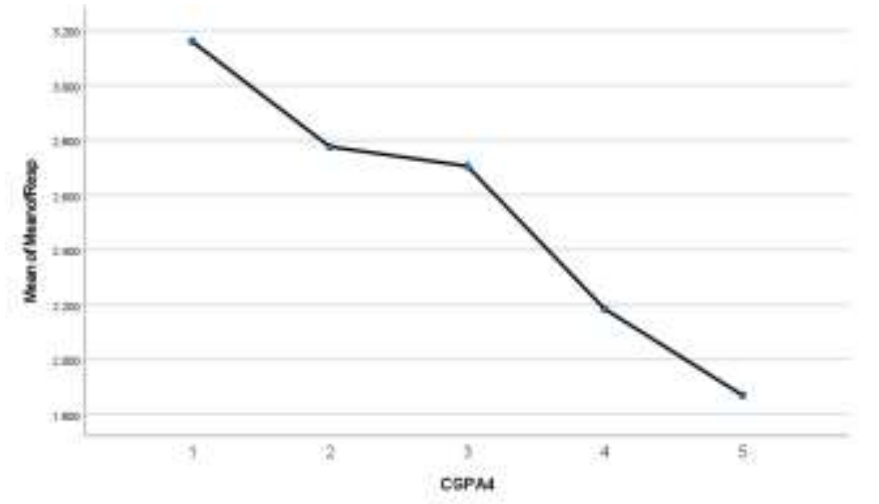

Fig. 3. Mean for Game Addiction with regards to CGPA.

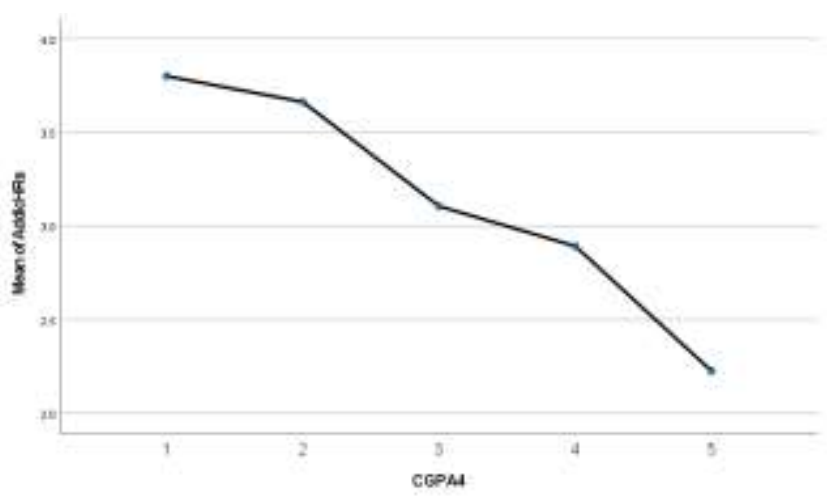

Fig. 4. Mean for Time Spent on Game Addiction with regards to CGPA.

The researchers have calculated the Pearson correlation and Significance One-Tailed Test of the CGPA and the mean of students' responses to the 20 survey questions. It was found that $\mathrm{r}$ (Pearson Correlation) is -.416. These results show a negative correlation between the CGPA and the mean of students' responses to the 20 survey questions at $\mathrm{p}$-value $=.000$ $<0.05$ (Table 7 and Table 8). 
TABLE VII. PEARSON CORRELATION OF THE CGPA AND THE MEAN OF STUDENTS' RESPONSES

\begin{tabular}{|l|l|l|l|}
\hline \multicolumn{2}{|l|}{ Correlations } & AddicHRs & CGPA4 \\
\hline \multirow{2}{*}{ Pearson Correlation } & AddicHRs & 1.000 & -.186 \\
\cline { 2 - 5 } & CGPA4 & -.186 & 1.000 \\
\hline \multirow{2}{*}{ Sig. (1-tailed) } & AddicHRs &. & .000 \\
\cline { 2 - 5 } N & CGPA4 & .000 &. \\
& AddicHRs & 417 & 417 \\
\cline { 2 - 5 } & CGPA4 & 417 & 417 \\
\hline
\end{tabular}

TABLE VIII. SIGNIFICANCE ONE-TAILED TEST OF THE CGPA AND THE MEAN OF STUdENTS' RESPONSES

\begin{tabular}{|c|c|c|c|c|c|c|c|c|}
\hline \multirow{2}{*}{\multicolumn{2}{|c|}{ Model }} & \multicolumn{2}{|c|}{ Unstandardized Coefficients } & \multirow{2}{*}{$\begin{array}{l}\text { Standardized Coefficients } \\
\text { Beta }\end{array}$} & \multirow{2}{*}{$\mathrm{t}$} & \multirow{2}{*}{ Sig. } & \multicolumn{2}{|c|}{$95.0 \%$ Confidence Interval for B } \\
\hline & & B & Std. Error & & & & Lower Bound & Upper Bound \\
\hline \multirow{2}{*}{1} & (Constant) & 4.391 & .382 & & 11.481 & .000 & 3.639 & 5.143 \\
\hline & CGPA4 & -.395 & .103 & -.186 & -3.848 & .000 & -.597 & -.193 \\
\hline
\end{tabular}

TABLE IX. PeArson Correlation of the CGPA AND the Number of AdDiction Hours

\begin{tabular}{|l|l|l|l|}
\hline \multicolumn{2}{|l|}{ Correlations } & VAR00027 & CGPA4 \\
\hline \multirow{3}{*}{ Pearson Correlation } & VAR00027 & 1.000 & -.416 \\
\cline { 2 - 5 } & CGPA4 & -.416 & 1.000 \\
\hline \multirow{2}{*}{ Sig. (1-tailed) } & VAR00027 &. & .000 \\
\cline { 2 - 5 } & CGPA4 & .000 &. \\
\hline \multirow{2}{*}{$\mathrm{N}$} & VAR00027 & 417 & 417 \\
\cline { 2 - 5 } & CGPA4 & 417 & 417 \\
\hline
\end{tabular}

TABLE X. SignificANCE ONE-TAILED TeSt OF THE CGPA AND THE Number OF ADDICTION Hours

\begin{tabular}{|c|c|c|c|c|c|c|c|c|}
\hline \multirow{2}{*}{\multicolumn{2}{|c|}{ Model }} & \multicolumn{2}{|c|}{ Unstandardized Coefficients } & \multirow{2}{*}{$\begin{array}{l}\text { Standardized Coefficients } \\
\text { Beta }\end{array}$} & \multirow{2}{*}{$\mathrm{t}$} & \multirow{2}{*}{ Sig. } & \multicolumn{2}{|c|}{$95.0 \%$ Confidence Interval for B } \\
\hline & & B & Std. Error & & & & Lower Bound & Upper Bounc \\
\hline \multirow{2}{*}{1} & (Constant) & 3.550 & .130 & & 27.224 & .000 & 3.294 & 3.807 \\
\hline & CGPA4 & -.326 & .035 & -.416 & -9.323 & .000 & -.395 & -.258 \\
\hline
\end{tabular}

The researchers have calculated the Pearson correlation and Significance One-Tailed Test of the CGPA and the number of addiction hours. It was found that $r$ (Pearson Correlation) is .186. These results show a negative correlation between CGPA and the number of addiction hours at $\mathrm{p}$-value $=.000<0.05$ (Table 9 and Table 10).

\section{CONCLUSION}

Covid-19 pandemic changed the lifestyles of many students. At the same time, video games are thought to have a negative impact on students; it is believed that playing digital games has become a global relaxation activity among students and people in general. However, published research suggests that an important number of university students tend to play games excessively, which could be damaging their physical and mental well-being [1, 23]. Therefore, the World Health
Organization [24] has recently included gaming disorder as a diagnosable mental disorder in the International Classification of Diseases (ICD) revision.

One of the objectives of the current study is to explore the deviations in online gaming behavior among university students in the context of COVID-19 between May 2020 and May 2021. This study revealed an important difference between May 2020 students' online games addiction and May 2021 students' online games addiction. Specifically, in May 2021, students are less addicted to online games. This is quite normal as students had increased their gaming behavior during the lockdown period following COVID-19 pandemic. The average addiction hours for students who were surveyed in May 2020 decreased from 3 hours in May 2020 to 2.84 in May 2021. 
The present study had also found that video game addiction levels differ significantly according to gender. Female students had lower levels of video game addiction than males. In addition, female students play online games less than male students. The result of the t-test had also shown gender differences in time spent playing video games. Female students spend less time playing video games. The findings of this study are consistent with that of $[17,25,26,27,28,29]$.

The result of the one-way ANOVAs test had shown no significant relationship between age and video game addiction. This is logical because the participant and university student's age, in general, falls within a close age group of 18-25. However, the t-test had also shown an important correlation between the academic level and video game addiction. First to third-year students are more addicted to video games than fourth- and fifth-year students. This is due to the higher maturity of the fourth- and fifth-year students.

The result of the study showed that video game addiction has a significant impact on academic performance. This finding is consistent with that of $[17,30,31]$, who saw a lower academic performance in students who engaged in playing video games. In addition, a negative correlation between students' CGPA and the number of hours they spend daily playing online games was found. As the CGPA increases, the number of addiction hours decreases, supporting the theory that academic performance can be negatively affected if the student is addicted to online video games.

Higher education institutions should take necessary actions to ensure that online video games cannot have a negative impact on educational achievement by:

1) Organize regular workshops and seminars to increase the population's awareness about the risk of video games' addiction and how to manage its use.

2) Integrating video games that promote critical thinking in the learning process so that this gaming addiction will turn up to be a catalyst for learning and improve students' academic performance, instead of decreasing academic CGPA.

Higher education institutions are constantly evolving by shifting their pedagogical approach from lecture-centered to student-centered and integrating the use of games as innovative learning technologies into their curricula.

\section{VII.LIMITATION AND FUTURE WORK}

\section{A. Limitation}

The current study could serve as a driving force for future research focusing on online game addictions. However, one should interpret the data carefully as the sample was limited to one university in the United Arab Emirates.

\section{B. Future Work}

1) Include students from other universities would provide better opportunities to understand the impact of game addiction on academic performance among university students in general.

2) Track students' behavior during their whole academic journey would give a more accurate account of the CGPA and video gaming and produce more precise data to assess students' gaming habits and CGPA scores for four or five years.

3) The research could also be extended to include online gaming disorder, depressive, and anxiety symptoms among university students.

4) Finally, the research could be extended to cover the impact of online gaming on time management and the social life of university students.

\section{REFERENCES}

[1] Johnson J., (2021), Leading online markets based on penetration rate 2021, https://www.statista.com/statistics/227082/countries-with-thehighest-internet-penetration-rate/.

[2] Javed, J. (2020). eSports and gaming industry thriving as video games provide escape from reality during coronavirus pandemic.

[3] Perez, M. (2020). Video games are being played at record levels as the coronavirus keeps people indoors.

[4] Pantling, A. (2020). Gaming usage up 75 percent amid coronavirus outbreak, Verizon reports. Retrieved from https://www.hollywoodreporter.com/news/gaming-usage-up-75percentcoronavirus-outbreak-verizon-reports-1285140.

[5] Stephen, B. (2020). This is Twitch's moment [internet]. Retrieved from https://www.theverge.com/2020/3/18/21185114/twitchyoutube-

[6] Abel, T., \& McQueen, D. (2020). The COVID-19 pandemic calls for spatial distancing and social closeness: not for social distancing!.

[7] Mishra, J., Anguera, J. A., \& Gazzaley, A. (2016). Video games for neuro-cognitive optimization. Neuron, 90(2), 214-218.

[8] Carbonell, X., Chamarro, A., Oberst, U., Rodrigo, B., \& Prades, M. (2018). Problematic use of the internet and smartphones in university students: 2006-2017. International journal of environmental research and public health, 15(3), 475.

[9] De Pasquale, C., Chiappedi, M., Sciacca, F., Martinelli, V., \& Hichy, Z. (2021). Online videogames use and anxiety in children during the COVID-19 pandemic. Children, 8(3), 205.

[10] Marinoni, G., van't Land, H., \& Jensen, T. (2020). The impact of Covid19 on higher education around the world. IAU Global Survey Report. International Association of Universities (IAU). https://www. youtube.com/channel/UCT5nt5FGVklxrtUHinF_LFA.

[11] Rüth, M., \& Kaspar, K. (2020). Commercial video games in school teaching: two mixed methods case studies on students' reflection processes. Frontiers in psychology, 11, 3802.

[12] Almalki, A. A., \& Aldajani, H. M. (2021). Impact Of Playing Video Games On The Social Behavior And Academic Performance Of Medical Student In Taif City. International Journal of Progressive Sciences and Technologies, 24(1), 572-585.

[13] Miller, C. T. (Ed.). (2008). Games: Purpose and potential in education. Springer Science \& Business Media.

[14] Clark, A., \& Ernst, J. (2009). Gaming research for technology education. Journal of STEM Education, 10(1).

[15] Alqurashi, M., Almoslamani, Y., \& Alqahtani, A. (2016). Middle School Students' Digital Game Eperiences in the City of Makkah in Saudi Arabia. IJAEDU-International E-Journal of Advances in Education, 2(4), 167-175.

[16] Ashton, D. (2011). Playstations and workstations: identifying and negotiating digital games work. Information Technology \& People.

[17] Wright, J. (2011). The effects of video game play on academic performance. Modern psychological studies, 17(1), 6 .

[18] Anand, V. (2007). A study of time management: The correlation between video game usage and academic performance markers. CyberPsychology \& Behavior, 10(4), 552-559.

[19] Wack, E., \& Tantleff-Dunn, S. (2009). Relationships between electronic game play, obesity, and psychosocial functioning in young men. CyberPsychology and Behavior, 12(2), 241-244.

[20] Jackson, L., Zhao, Y., Kolenic III, A., Fitzgerald, H., Harold, R., \& Von Eye, A. (2008). Race, gender, and information technology use: The new digital divide. CyberPsychology and Behavior, 11(4), 437-442. 
[21] Wood, R., Griffiths, M., \& Parke, A. (2007). Experiences of time loss among videogame players: An empirical study. CyberPsychology and Behavior, 10(1), 38-44.

[22] Jaruratanasirikul, S., Wongwaitaweewong, K., \& Sangsupawanich, P. (2009). Electronic game play and school performance of adolescents in southern Thailand. CyberPsychology and Behavior, 12(5), 509-512.

[23] Stevanović, D., Đoric, A., Balhara, Y., Ćirović, N., Arya, S., Ransing, R., ... \& Knez, R. (2020). Assessing the symptoms of Internet Gaming Disorder among college/university students: An international validation study of a self-report. Psihologija, 53(1), 43-63.

[24] World Health Organization. (2020). \#HealthyAtHome - Mental Health. Retrieved from https://www.who.int/news-room/campaigns/connectingthe-world-to-combat-coronavirus/healthyathome/healthyathomemental-health.

[25] Gómez-Galán, J., Lázaro-Pérez, C., \& Martínez-López, J. '(2021). Exploratory Study on Video Game Addiction of College Students in a Pandemic Scenario. Journal of New Approaches in Educational Research, 10(2), 330-346. doi: 10.7821/naer.2021.7.750.

[26] Miezah D, Batchelor J, Megreya AM, Richard Y, Moustafa AA. Video/Computer Game Addiction among University Students in Ghana: Prevalence, Correlates and Effects of Some Demographic Factors. Psychiatry and Clinical Psychopharmacology 2020;30(1):17-23, DOI:10.5455/PCP.20200320092210.
[27] Bekir S., Çelik E., An Investigation of Online Gaming Addiction Level Among University Students in Terms of Emotional Schemas, Agentic Personality, and Various Variables, Malaysian Online Journal of Educational Technology 2020 ,Volume 8 (3).

[28] Müezzin E., An Investigation of High School Students' Online Game Addiction With Respect To Gender, TOJET: The Turkish Online Journal of Educational Technology - July 2015, Special Issue 1 for IETC 2015, pp. $55-60$.

[29] Dennis O. Dumrique and Jennifer G. Castillo, (2018), "Online Gaming: Impact on the Academic Performance and Social Behavior of the Students in Polytechnic University of the Philippines Laboratory High School" in 4th International Research Conference on Higher Education, KnE Social Sciences, pages 1205-1210. DOI 10.18502/kss.v3i6.2447.

[30] Gómez-Gonzalvo F., Cardenal Herrera, José Devís-Devís, Dr. Pere Molina-Alventosa, Video game usage time in adolescents' academic performance, Comunicar, Vol. XXVIII,No 652020 | Media Education Research Journal | ISSN: 1134-3478; e-ISSN: 1988-3478 www.comunicarjournal.com.

[31] Almalki A., Aldajani, H., 2020, Impact of Playing Video Games On The Social Behavior And Academic Performance Of Medical Student In Taif City, International Journals of Sciences and High Technologies http://ijpsat.ijsht-journals.org Vol. 24 No. 1 December 2020, pp. 572585. 